\title{
HEALTH KNOWLEDGE AND ATTITUDE PRACTICES IN PAKISTANI HAJJ PILGRIMS.
}

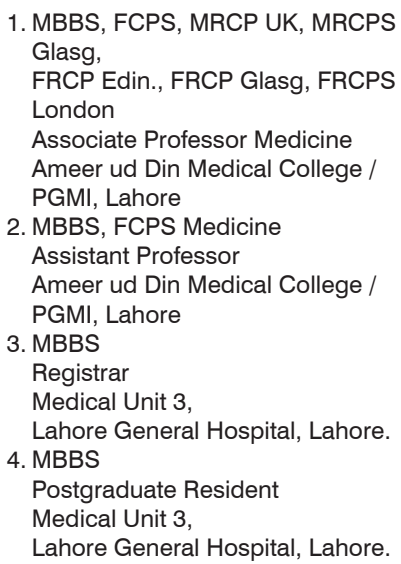

\section{Correspondence Address:}

Dr. M. Imran Hassan Khan

Associate Professor Medicine

Ameer ud Din Medical College / PGMI,

Lahore

mimranhkhan@hotmail.com

Article received on:

31/07/2019

Accepted for publication:

21/10/2019

\section{Muhammad Imran Hassan Khan', Kashif Aziz Ahmad², Salman Shakeel ${ }^{3}$, Muhammad Qasim}

ABSTRACT... Background: Pakistan has one of the highest number of Hajj pilgrims among all Islamic countries. Health of pilgrims play an important role in performing rituals of Hajj. It depends on their knowledge and attitude about health. Aims: In this study, we aimed to determine the Knowledge and Attitude about health in Pakistani Hajj pilgrims. Study Design: Questionnaire based prospective cross-sectional study. Setting: Lahore General Hospital, Pakistan. Period: June to August 2018. Material \& Methods: 150 Pakistani Hajj pilgrims were randomly selected. Data was collected using a questionnaire. The questionnaire consisted of demographic information (sex, age, previous chronic ailment), health knowledge (4 questions) and health attitude (12 questions). Results: There were more males (71.3\%) than females (28.7\%). Most participants were between 31 to 50 years (48.7\%), above 50 (30 \%), $20 \%$ below 30 years and only $1.3 \%$ above 70 years. Majority (62.7\%) had no previous illness, $8.7 \%$ had diabetes, $11.3 \%$ Hypertension, 1.3\% cirrhotic, and 16\% had more than one co-morbidity. Level of knowledge was best in hand hygiene (100\%) and vaccination (86.7\%), but least in heat stroke $32.7 \%$ and chronic ailment 30.7\%. Regarding attitude, $64 \%$ had positive attitude for wearing mask, $20.7 \%$ knew 5 movements, $77.3 \%$ food handling, $84 \%$ using one time razor for shaving, $25.3 \%$ features of heat stroke, $19.3 \%$ knew management of heat stroke, $97.3 \% \mathrm{knew}$ about wearing light colored clothes, $30.7 \%$ for maintaining medicine of previous illness, $78 \%$ followed same diet precaution, $9.3 \%$ aware on carrying medicine, $4 \%$ on wearing medic alert bracelet. $86.7 \%$ had positive attitude for polio vaccine, $83.3 \%$ for influenza vaccine, $84.7 \%$ for meningitis vaccine and $82.7 \%$ for pneumonia vaccine. Conclusions: Educational strategy is required to improve knowledge and attitude on heat stroke and chronic ailment management.

Key words: $\quad$ Attitudes, Education, Hajj Pilgrims, Knowledge, Stroke, Vaccination.

Article Citation: Khan MIH, Ahmad KA, Shakeel S, Qasim M. Health Knowledge and Attitude Practices in Pakistani Hajj Pilgrims. Professional Med J 2020; 27(2):359364. DOI: 10.29309/TPMJ/2020.27.2.3988

\section{INTRODUCTION}

The annual pilgrimage to Makkah Saudi Arabia, is known as Hajj. Gathering varies from 2 to 3 million people from more than 193 Countries. Living, drinking, eating and sleeping in close lodgings, in a new climate poses many challenges. Pakistan is one of the countries with highest number of pilgrims. With the expectation that Muslim population will rise from the 2010 consensus of 1.6 billion to around 2.8 billion in 2050 , the number of pilgrims will also rise. ${ }^{1}$ Overcrowding creates many issues, which include infections, hygiene related issues, food handling problems, extremes of temperature and moving with co-morbid illnesses in the background. Infectious diseases are a very important cause of morbidity in places where huge crowds of people are in attendance.
Major infections are respiratory, gastrointestinal, skin related, eyes and aggravation of chronic infective issues. ${ }^{2}$ These pilgrims can carry infections back to their homelands, increasing the possibility of pandemics. ${ }^{3}$ Other than infections, hygiene is difficult to maintain in this condition. Rituals are also such that it is forbidden to cover heads in males or apply perfumes. ${ }^{4}$ Females have other prohibitions like fully covered gear with face open, exposing them to extremes of sweat and heat. Food handling and sharing carries a lot of risk for food and water borne health issues. ${ }^{5}$ Extreme heat of the country causes problems with food storage and dehydration. ${ }^{6}$ One major over looked aspect is people travelling with comorbid illnesses and poor education on how to handle the situation. For this reason, the Saudi 
Government issues guidelines every now and then, to facilitate the pilgrims. ${ }^{7}$

Pakistani contingent has one the highest proportion of pilgrims in Hajj. Very few studies have highlighted issues properly. One study stressed respiratory infections in Iran and Indonesia. ${ }^{8}$ There is another study which explored barriers of preventive measures amongst Australian pilgrims. ${ }^{1}$ In a different study in France, they emphasized the unawareness of pilgrims to barrier methods of infectious diseases. There is documentation of heat related issues faced by patients during hajj. ${ }^{6}$ Management of chronic illness is also another important aspect in which patient knowledge is deficient. ${ }^{9}$ these studies are deficient from our perspective, because we live in a different environment. Our culture and diet habits are different, so are the prevalent infections like polio. Literature is still deficient in evidence, addressing awareness and insight into disease prevention and control amongst Pakistani pilgrims. ${ }^{10}$

Keeping in view this objective, we carried out our study to assess the knowledge and attitude of Pakistani Hajj pilgrims, and executed it in pre hajj period of 2018. We expected that it will help in identifying the deficient areas, which can be targeted by the competent authorities, to improve health in our pilgrims.

\section{MATERIALS AND METHODS}

It was a questionnaire based prospective, crosssectional, descriptive study, carried out in 150 Pakistani Hajj pilgrims, who were randomly selected between June to August 2018. This study was approved by the Ethical Review Committee of Ameer ud Din Medical College, Lahore. Selection points for patients included Lahore General Hospital, Haji camp near Lahore railway station and few running clinics in Lahore. In addition, major pool of patients was selected after advertisement. Posters were displayed in different areas of city, with contact number of the focal person (Figure: 1). A workshop was carried out for doctors, within hospital and outside, who were trained on the questionnaire. Only one of the trained doctor was practically involved in the study with a dedicated cell phone line. Patients either visited or called him directly with their questions, who were then included to participate after consent. In the data collected, questions consisted of demographic information (sex, age, previous chronic ailment), health knowledge (4 questions), health attitude (12 questions). These questions were selected from the Saudi Government online guidelines 2018 for the Hajj pilgrims, encompassing the infection control, heat stroke, hygiene and travel advice for chronically ill patients. All the answers were taken as yes or no, and recorded. Questionnaire was not developed after any pilot study, rather it was validated by local experts in the field. Reliability was ascertained by Cronbach alpha of 0.82 . Statistical analysis was done using SPSS software version 19.0 (SPSS Inc, Chicago, USA). Data was analyzed using $t$ test. A P value of 0.05 was considered significant.

\section{RESULTS}

There were more males (71.3\%) in the study than females (28.7\%). Most participants were between 31 to $50(48.7 \%)$ years of age, followed by people above 50 (30\%), while only $20 \%$ were below 30 years. Only $1.3 \%$ were above 70 years of age (Table-I).

\begin{tabular}{|c|c|}
\hline $\begin{array}{c}\text { Variable } \\
\text { Frequency, No. (\%) }\end{array}$ & $\begin{array}{c}\text { Variable } \\
\text { Frequency, No. (\%) }\end{array}$ \\
\hline Gender & $107(71.3)$ \\
\hline Male & $43(28.7)$ \\
\hline Female & $30(20)$ \\
\hline AGE, Y & $73(48.7)$ \\
\hline $1-30$ & $45(30)$ \\
\hline $31-50$ & $2(1.3)$ \\
\hline $51-70$ & \\
\hline$>70$ & \\
\hline Table-I. Socio-demographic Characteristics.
\end{tabular}

Majority had no previous illness (62.7\%), with 8.7 $\%$ having diabetes, $11.3 \%$ Hypertension, 1.3\% cirrhotic, and $16 \%$ had more than one co-morbidity (Table-II). Level of knowledge was best in hand hygiene (100\%) and less in heat stroke $32.7 \%$, with knowledge about vaccination at $86.7 \%$ and chronic ailment $30.7 \%$. Hence hand hygiene and vaccination were best knowledgeable areas, and Heat stroke and management of chronic ailment were least (Table-III). 


\begin{tabular}{|c|c|c|}
\hline $\begin{array}{c}\text { Variable } \\
\text { Frequency, No. (\%) }\end{array}$ & \multicolumn{2}{|c|}{$\begin{array}{l}\text { Variable } \\
\text { Frequency, No. (\%) }\end{array}$} \\
\hline Diabetes & \multicolumn{2}{|c|}{$13(8.7)$} \\
\hline Hypertension & \multicolumn{2}{|c|}{$17(11.3)$} \\
\hline Cirrhosis & \multicolumn{2}{|c|}{$2(1.3)$} \\
\hline More than One & \multicolumn{2}{|c|}{$24(16)$} \\
\hline No Co Morbidity & \multicolumn{2}{|c|}{$94(62.7)$} \\
\hline \multicolumn{3}{|c|}{ Table-II. History of Chronic Ailment. } \\
\hline Variable & Yes & No \\
\hline $\begin{array}{l}\text { Will you maintain Hygiene } \\
\text { during Hajj? }\end{array}$ & $150(100 \%)$ & 0 \\
\hline $\begin{array}{l}\text { Do you know about Heat } \\
\text { Stroke? }\end{array}$ & $49(32.7 \%)$ & $101(67.3 \%)$ \\
\hline $\begin{array}{l}\text { Have you contacted doctor } \\
\text { for chronic ailment? }\end{array}$ & $46(30.7 \%)$ & $104(69.3 \%)$ \\
\hline $\begin{array}{l}\text { Have you got your } \\
\text { vaccination? }\end{array}$ & $\begin{array}{c}130 \\
(86.7 \%)\end{array}$ & $20(13.3 \%)$ \\
\hline \multicolumn{3}{|c|}{ Table-III. Level of Knowledge Assessment. } \\
\hline \multicolumn{3}{|c|}{$\begin{array}{l}\text { ROUND THE CLOCK TELEPHONIC HELPLINE } \\
\text { FOR MEDICAL PATIENTS GOING TO HAJJ } 2018\end{array}$} \\
\hline \multicolumn{3}{|c|}{ 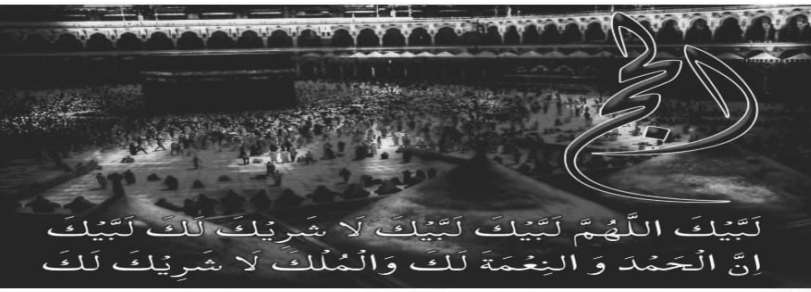 } \\
\hline \multicolumn{3}{|c|}{$\begin{array}{l}\text { Let us help you in your journey of a life time } \\
\text { Call or WhatsApp us 24- hours a day, } 7 \text { days a week with any question regarding your medical condition } \\
\text { @ 0306-5399125 }\end{array}$} \\
\hline \multicolumn{3}{|c|}{$\begin{array}{l}\text { OR Visit in person@ DEMC, OPD ROOM NO: } 80 \\
\text { Lahore General Hospital MON-SATURDAY 8AM TO 2PM }\end{array}$} \\
\hline \multicolumn{3}{|c|}{ Figure 1: Hajj Poster } \\
\hline
\end{tabular}

Regarding attitude, 64\% had positive attitude towards wearing a mask, only $20.7 \%$ knew about correct hand hygiene movements, $77.3 \%$ had positive attitude for food handling, $84 \%$ had positive attitude for shaving with one time razor, 25.3\% already had knowledge and positive attitude towards heat stroke features, $19.3 \%$ about management of heat stroke, while $97.3 \%$ knew to wear light coloured clothes. $30.7 \%$ knew that they had to keep same dose of medicine for previous illness, $78 \%$ had positive attitude for following diet precaution, 9.3\% knew and wanted to carry medicine for previous illness. Only $4 \%$ had awareness on wearing medic alert bracelet. $86.7 \%$ had positive attitude for polio vaccine, $83.3 \%$ for influenza vaccine, $84.7 \%$ for meningitis vaccine and $82.7 \%$ for pneumonia vaccine (TableIV). Hence vaccination knowledge and attitude were better.

\begin{tabular}{|c|c|c|}
\hline Variable & $\begin{array}{c}\text { Compliance } \\
\text { N (\%) }\end{array}$ & $\begin{array}{c}\text { Non- } \\
\text { compliance } \\
\text { N (\%) }\end{array}$ \\
\hline Wearing face-mask & $96(64)$ & $54(36)$ \\
\hline $\begin{array}{l}\text { Hand hygiene } 5 \\
\text { movements }\end{array}$ & $31(20.7)$ & $119(79.3)$ \\
\hline Food handling & $116(77.3)$ & $34(22.7)$ \\
\hline $\begin{array}{l}\text { Shaving with once use } \\
\text { razors }\end{array}$ & $126(84)$ & $24(16)$ \\
\hline Features of Heat Stroke & $38(25.3)$ & $24(16)$ \\
\hline $\begin{array}{l}\text { Management of Heat } \\
\text { Stroke }\end{array}$ & $29(19.3)$ & $121(80.7)$ \\
\hline $\begin{array}{l}\text { Light Cloth colors to be } \\
\text { used }\end{array}$ & $146(97.3)$ & $4(2.7)$ \\
\hline $\begin{array}{l}\text { Maintain same } \\
\text { medication dose }\end{array}$ & $46(30.7)$ & $104(69.3)$ \\
\hline $\begin{array}{l}\text { Maintaining same diet } \\
\text { precautions }\end{array}$ & $117(78)$ & $33(22)$ \\
\hline How to carry medicine & $14(9.3)$ & $136(90.7)$ \\
\hline Medic alert bracelet & $6(4)$ & $144(96)$ \\
\hline \multicolumn{3}{|l|}{ VACCINATION } \\
\hline Polio & $130(86.7)$ & $20(13.3)$ \\
\hline Influenza & 125 (83.3) & $25(16.7)$ \\
\hline Meningitis & $127(84.7)$ & $23(15.3)$ \\
\hline Pneumonia & $124(82.7)$ & $26(17.3)$ \\
\hline
\end{tabular}

\section{DISCUSSION}

Knowledge of Pakistani Hajj pilgrims was good in few areas, and ignorant in the other. Four particular areas were checked in this study, including Hygiene, vaccination, heat stroke and travel with different co-morbid illnesses and knowledgeabout their management. Hygiene was among the best knowledge areas, and pilgrims were aware about hand washing, maintaining cleanliness in general, using face mask, shaving practices with one time use razors, food handling and protecting food at appropriate places if required to save it for longer period. Similar good knowledge was observed for vaccination of all four infectious diseases mentioned in the Saudi Guidelines, namely Polio, Meningitis, Influenza and Pneumonia. The level of knowledge and practice of getting vaccinated 
was also good and in the same order, with Polio highest and Pneumonia lowest. In recent years, there has been a lot of emphasis on the spread of infections during Hajj, which could cause potentially a pandemic. Pakistan is in WHO list of countries where polio is still not eradicated. There are international obligations which require pilgrims to travel only after vaccination. ${ }^{11}$ This is a big reason for awareness among all travellers from this region to get recommended vaccination. Zafer et $\mathrm{al}^{12}$ have also documented in their study of similar pattern, with falling infections during hajj due to better steps taken by governments.

Protection from sun, hot temperature and travel requirements with chronic diseases were among those areas which were poorly followed in our study. Sindy et $\mathrm{al}^{13}$ documented in their study that there was an equal distribution of diseases in different age groups. Majority pilgrims were in the group between 50 to 69 , whereas there was equal distribution in every 10 year age distribution below 50. They also showed that the majority patients attending Arafat had bronchial asthma or suffered injury, which was followed by diabetes and associated diseases, ischemic heart disease, heat effects, gastroenteritis and dehydration. Our study was similar with this study as major chunk of our patients also had diabetes as a single disease or in combination with diseases. However, there were more differences. First, our study assessed the knowledge and attitudes through questionnaire before hajj. There were more people in the study between the age group of 31 to 50 , suggesting that relatively younger people go to hajj from this area. It was also noted that majority of patients going to hajj had no co-morbid illness, but among those having illness, hypertension was more common than diabetes. However, there were more patients with a combination of diseases, than single disease. This suggests that our pilgrims were more healthy, after which there were more travellers with combination of diseases than single disease. Regarding knowledge and attitude about heat stroke and management of chronic ailments, our patients were more ignorant, and did not contacted their doctor for travel advice before journey. Hence, there was need to address both these issues to prevent problems futuristically.

Memish et $\mathrm{al}^{4}$ documented that hajj can cause rapid transmission of pathogens related with respiratory tract, and wearing face mask along with other ways was effective in reducing spread of these infections. When we checked attitude of our patients, we concluded that there was $64 \%$ compliance with it. Hence there was a need to improve this attitude. Adegboye et al $^{14}$ documented in ICU workers that the knowledge of WHO recommendations of 5 movements of hand were good, but when it comes to implementation, the results were poor. In our study, we were checking this information on general public, which was different. Only $21 \%$ of people going for hajj were aware and documented correct movements. There is scope to improve knowledge of pilgrims, which can also significantly reduce infection transmission. Despite being unaware on hand hygiene technique, majority of pilgrims knew and practiced food handling precautions and shaving from one time use razors.

Regarding heat stroke, al-Bakry et al ${ }^{15}$ documented that there is a large proportion of patients suffering from heat related problems due to sudden change of climate. They also documented that it was frequently under diagnosed and led to complications. They suggested doing pulse oximetry of patients to document hypoxia in these patients. Our study was different as it assessed that not only our patients were not informative about the features of heat stroke, there was lack of information on management of this condition. However, one step in management was well perceived in their attitudes, which was wearing light coloured cloths. Possible reason was unknown, and we don't know if there is any role of education given by health providers.

Gagneux-Brunon et $\mathrm{al}^{9}$ documented in their study on chronic ailment disease patients that most frequent were diabetes and hypertension. They also noted that Hajj pilgrims were more likely to come and report of chronic ailment. Our results were different, as majority patients were normal with no ailment. Among diseased patients, more than two disease patients were more common, 
followed by hypertension and then diabetes. The reason for this difference could be social, environmental or cultural. We have observed that patients going to hajj, do contact their doctors to get a prescription for trivial illness, but do not follow chronic disease prescription. In our study, patients documented poor knowledge and attitude in maintaining same dose of medicine during hajj and on carrying medicine. However, they were aware of carrying with same dietary restrictions during pilgrim. The attitude to wear medic alert bracelet was also very poor in our patients which requires improvement.

Razavi et $\mathrm{al}^{16}$ documented in their review article that almost $100 \%$ of pilgrims were vaccinated for meningococcus, but vaccination for influenza and pneumococcus were questionable. The efficacy of influenza flu vaccine was also questionable and less effective in majority. Polio was not mentioned in their study as it was not a global problem. It was different from our study in many respects. First, our study was performed before going to hajj, and their studies were during hajj. Hence there were chances that people were not vaccinated when they contacted us in our study. Our data was most strong for polio which was not mentioned in their study. This spoke loudly about the efforts put in to eradicate polio from this region. Knowledge about influenza, meningitis and pneumonia vaccine were also very good and almost equal with minor difference, and the attitude to get vaccinated was also excellent. We can deduce from here that similar efforts can be done on other areas of patient knowledge and attitude.

There were few limitations in our study. First, this study was carried out before hajj departure of pilgrims. There were areas of knowledge and attitude, which were carried out later by their tour operators in haji camps. Hence we were early to carry out this study. Second, the number of participants was small in this study. We found it difficult to convince people to participate, although we used different ways for this purpose. Third, there was no pilot study carried out for the questionnaire. It was built on the Saudi Government guidelines for Hajj 2018, validated by local experts and reliability was performed through Cronbach alpha value of 0.82 from respondent's answers. Fourth, we were unable to find out strong local data. This study may be a step to improve it as Pakistan had more than 179,000 official number of hajj pilgrims. ${ }^{17},{ }^{18}$

\section{CONCLUSION}

The knowledge of our pilgrims was adequate on maintaining hygiene during hajj as well as vaccination. Steps taken were effective. However, knowledge on heat stroke was deficient along with the management steps. Same were the findings with people travelling with chronic illness, who were not aware to travel with all prescribed medicine and to take them regularly during hajj. There was a need to take effective steps in both these areas, to decrease patient sufferings.

Copyright $@ 21$ Oct, 2019.

\section{REFERENCES}

1. Alqahtani AS, Tashani M, Heywood AE, Booy R, Rashid $H$, Wiley KE. Exploring Australian Hajj Tour Operators' Knowledge and Practices Regarding Pilgrims' Health Risks: A Qualitative Study. JMIR Public Health Surveill. 2019;5(2):e10960.

2. Benkouiten S, Al-Tawfiq JA, Memish ZA, Albarrak $A$, Gautret $P$. Clinical respiratory infections and pneumonia during the Hajj pilgrimage: A systematic review. Travel Med Infect Dis. 2019 Apr;28:15-26.

3. Leangapichart T, Dia NM, Olaitan AO, Gautret P, Brouqui $\mathrm{P}$, Rolain J-M. Acquisition of Extended-Spectrum $\beta$-Lactamases by Escherichia coli and Klebsiella pneumoniae in Gut Microbiota of Pilgrims during the Hajj Pilgrimage of 2013. Antimicrob Agents Chemother. 2016;60(5):3222-6.

4. Memish ZA, Assiri A, Turkestani A, Yezli S, Masri M al, Charrel $R$, et al. Mass gathering and globalization of respiratory pathogens during the 2013 Hajj. Clin Microbiol Infect. 2015 Jun 1;21(6):571.e1-571.e8.

5. Al-Joudi AS. An outbreak of foodborne diarrheal illness among soldiers in mina during hajj: the role of consumer food handling behaviors. J Fam Community Med. 2007 Jan;14(1):29-33.

6. Abdelmoety DA, El-Bakri NK, Almowalld WO, Turkistani ZA, Bugis BH, Baseif EA, et al. Characteristics of Heat Illness during Hajj: A Cross-Sectional Study. BioMed Res Int. 2018;2018:5629474. 
7. Health Guidelines - During Hajj [Internet]. [cited 2019 May 7]. Available from: https://www.moh.gov.sa/en/ Hajj/HealthGuidelines/Pages/DuringHajj.aspx

8. Alfelali M, Barasheed O, Tashani M, Azeem MI, El Bashir $H$, Memish ZA, et al. Changes in the prevalence of influenza-like illness and influenza vaccine uptake among Hajj pilgrims: A 10-year retrospective analysis of data. Vaccine. 2015 May 21;33(22):2562-9.

9. Gagneux-Brunon A, Andrillat C, Fouilloux P, Daoud F, Defontaine C, Charles R, et al. Pre-travel advice seeking from GPs by travellers with chronic illness seen at a travel clinic. J Travel Med. 2016 Mar;23(3).

10. Bakhsh AR, Sindy Al, Baljoon MJ, Dhafar KO, Gazzaz ZJ, Baig M, et al. Diseases pattern among patients attending Holy Mosque (Haram) Medical Centers during Hajj 1434 (2013). Saudi Med J. 2015 Aug;36(8):962-6.

11. Mushtaq A, Mehmood S, Rehman MAU, Younas A, Rehman MSU, Malik MF, et al. Polio in Pakistan: Social constraints and travel implications. Travel Med Infect Dis. 2015 Oct;13(5):360-6.

12. Zafer N, Dulong C, Rahman A, Tashani M, Alfelali M, Alqahtani $A S$, et al. Acute respiratory tract infection symptoms and the uptake of dual influenza and pneumococcal vaccines among Hajj pilgrims. Int Marit Health. 2018;69(4):278-84.
13. Sindy AI, Baljoon MJ, Zubairi NA, Dhafar KO, Gazzaz ZJ, Deiab BA, et al. Pattern of patients and diseases during mass transit: The day of Arafat experience. Pak J Med Sci. 2015;31(5):1099-103.

14. Adegboye MB, Zakari S, Ahmed BA, Olufemi GH. Knowledge, awareness and practice of infection control by health care workers in the intensive care units of a tertiary hospital in Nigeria. Afr Health Sci. 2018 Mar;18(1):72-8.

15. el-Bakry AK, Channa AB, Bakhamees $H$, Turkistani $A$, Seraj MA. Heat exhaustion during mass pilgrimage-is there a diagnostic role for pulse oximetry? Resuscitation. 1996 Apr;31(2):121-6.

16. Razavi SM, Saeednejad M, Salamati P. Vaccination in Hajj: An Overview of the Recent Findings. Int J Prev Med. 2016;7:129.

17. Elachola H, Chitale RA, Ebrahim SH, Wassilak SGF, Memish ZA. Polio priority countries and the 2018 Hajj: Leveraging an opportunity. Travel Med Infect Dis. 2018 Oct;25:3-5.

18. Report W. Saudi Arabia increases Pakistan's Haj quota for 2019 [Internet]. Khaleej Times. [cited 2019 May 31]. Available from: https://www.khaleejtimes. com/international/pakistan/saudi-arabia-increasespakistans-haj-quota-for-2019

\begin{tabular}{|c|c|c|c|}
\hline \multicolumn{3}{|c|}{ AUTHORSHIP AND CONTRIBUTION DECLARATION } \\
\hline Sr. \# & Author(s) Full Name & \multicolumn{1}{|c|}{ Contribution to the paper } & Author(s) Signature \\
\hline 1 & M. Imran Hassan Khan & $\begin{array}{l}\text { Idea, Introduction, Review of } \\
\text { manuscript, Discussion, Final } \\
\text { approval. } \\
\text { Literature reivew, Introduction. }\end{array}$ \\
\hline 3 & Kashif Aziz Ahmad & Salman Shakeel & Literature review, Resutls. \\
\hline 4 & Muhammad Qasim & $\begin{array}{l}\text { Data collection, Results } \\
\text { calculation. }\end{array}$ \\
\hline
\end{tabular}

